\title{
16S/18S ribosomal DNA clone library analysis of rumen microbial diversity
}

\section{Aminov, Rustam}

\section{Published in:}

Methods in Gut Microbial Ecology for Ruminants

Link to article, DOI:

10.1007/1-4020-3791-0_13

Publication date:

2005

Document Version

Publisher's PDF, also known as Version of record

Link back to DTU Orbit

\section{Citation (APA):}

Aminov, R. (2005). 16S/18S ribosomal DNA clone library analysis of rumen microbial diversity. In Methods in Gut Microbial Ecology for Ruminants (pp. 163-174). Springer Netherlands. https://doi.org/10.1007/1-4020-37910_13

\section{General rights}

Copyright and moral rights for the publications made accessible in the public portal are retained by the authors and/or other copyright owners and it is a condition of accessing publications that users recognise and abide by the legal requirements associated with these rights.

- Users may download and print one copy of any publication from the public portal for the purpose of private study or research.

- You may not further distribute the material or use it for any profit-making activity or commercial gain

- You may freely distribute the URL identifying the publication in the public portal

If you believe that this document breaches copyright please contact us providing details, and we will remove access to the work immediately and investigate your claim 


\title{
5.1. $16 \mathrm{~S} / 18 \mathrm{~S}$ ribosomal DNA clone library analysis of rumen microbial diversity
}

\author{
ANDRÉ-DENIS G. WRIGHT ${ }^{1}$, KIYOSHI TAJIMA ${ }^{2}$ and RUSTAM I. AMINOV ${ }^{3}$ \\ ${ }^{1}$ CSIRO Livestock Industries, Centre for Environment and Life Sciences, Wembley, WA 6913, Australia \\ ${ }^{2}$ National Institute of Livestock and Grassland Science, National Agricultural Research Organization, \\ Tsukuba, Ibaraki 305-0901, Japan \\ and ${ }^{3}$ Rowett Research Institute, Aberdeen AB21 9SB, UK
}

\section{Introduction}

The rumen contains a complex ecosystem where billions of bacteria, archaea, protozoa and fungi reside. This diverse microbiota is well adapted to live in the rumen and play an important role in the digestion of feed and nutrient supply to the host in the form of microbial protein and volatile fatty acids. It is estimated that the rumen microbial population consists of about $10^{6}$ protozoa $/ \mathrm{ml}, 10^{3}-10^{7}$ fungi $/ \mathrm{ml}, 10^{10}$ bacteria $/ \mathrm{ml}$, and $10^{9}$ methanogens $/ \mathrm{ml}[11]$. To better understand the complex relationships in the rumen, it is necessary to gain an insight into the diversity of the rumen microbes and how the quantity and composition of rumen micro-organisms are altered by a number of different host factors such as age, genetics and diet.

In the past, the diversity of micro-organisms from the digestive tracts of domesticated ruminants has been identified by classical microbiological techniques [43]. However, given the fastidious growth requirements of rumen micro-organisms, it is reasonable to concede that the culture-dependent methods may select against some species, or taxonomic groups, leading researchers to underestimate the microbial diversity that is actually present in the rumen. In fact, it has been speculated that $90 \%$ of micro-organisms in nature have escaped traditional cultivation methods [35]. Therefore, a major challenge in microbial ecology has been to assess the diversity and structure of natural microbial communities.

The field of molecular biology has advanced with many innovative technological breakthroughs. The ability to extract and to isolate high-molecular weight DNA from rumen digesta, PCR amplify genes from specific microbial groups and obtain gene sequence data is now a routine event. The small subunit ribosomal RNA (SSUrRNA) gene, called $16 \mathrm{~S}$ in prokaryotes and $18 \mathrm{~S}$ in eukaryotes, is the most widely used molecular marker to presumptively identify morphologically indistinguishable species, to infer their phylogenetic relationships, and to elucidate microbial diversity. Furthermore, the retrieved SSU-rDNA sequence information lays a background for the development of other molecular detection techniques such as FISH, FISHFC, DNA microarrays and quantitative real-time PCR techniques. The application of molecular techniques has already revealed the enormous wealth of microbial diversity and putative novel species in the rumen $[15,17,21,22,30-32,34,39,40,45]$. In 
this Chapter, the main steps of SSU-rDNA library generation and analysis will be presented and discussed in detail.

\section{Overview of experimental approach}

In general, construction of SSU-rDNA libraries is started from obtaining a fresh sample of the rumen contents from fistulated domestic animals or wild ruminants and fractionation if desirable (rumen fluid, rumen solids and protozoal fractions). At this stage, the sample can be frozen at $-80^{\circ} \mathrm{C}$ for further analysis. Then the total DNA is isolated using either commercially available kits, bead-beating technique, freezing-thawing method or enzymatic lysis. Obviously, this total DNA preparation contains chromosomal DNA of all microbiota, including bacteria, archaea, fungi and protozoa, as well as the host's DNA from sloughed-off epithelial cells. To retrieve specific SSU-rDNA sequences from this mix, PCR amplification with primers that are specific for bacteria, archaea, fungi or protozoa is used. The number of cycles needs to be maintained low (i.e. 10-12 cycles) to avoid preferential amplification of certain templates and/or chimeric molecule formation $[3,42]$.

Commercially manufactured cloning kits are available to clone the PCR amplified $16 \mathrm{~S} / 18 \mathrm{~S}$ genes from your target group into specially designed plasmids. Positive clones (i.e. white colonies) are randomly selected and checked for the presence of expected size inserts by PCR amplification, this time using the vector primers that surround the insert. These recombinant clones now represent your library and the next step is to analyse them by sequencing.

In a randomly generated library, some clones are closely related and therefore redundant in terms of uncovering the whole diversity. Obviously, an initial selection step before proceeding to the complete sequencing is helpful to reduce the sequencing work while allowing the maximum diversity coverage in a library. This can be done by partial sequencing of PCR templates that were generated in the positive clone screening procedure of the previous step. For this, the PCR products are sequenced with one of the primers used for library production and the sequences are analysed for similarity. Sequences with similarity values $\geq 97 \%$ are considered to belong to the same operational taxonomic unit (OTU) and sequencing can be limited to the one representative OTU. This molecular species definition, OTU, is based on correlation between a DNA reassociation value and SSU-rDNA homology. In a polyphasic approach, the 'species' nomination includes bacteria that share a DNA reassociation value of about $70 \%$ [37], and this value corresponds to similarities of $97 \%$ and higher at the level of SSU-rDNA sequence [28]. For ecological community structure analysis, OTUs are considered as molecular species, while the number of sequences within an OTU represents the population of a given species. Complete sequencing of each representative OTU is done with several sequencing primers complementary to conserved regions of the SSU-rDNA molecule.

Alternatively, the taxonomic groups can be defined on the basis of restriction fragment length polymorphisms (RFLP), also called ribotypes. For this, instead of 
sequencing, the PCR fragments are digested with a combination of frequent-cutting restriction enzymes according to the manufacturers specifications. Digested DNA is separated on 3-4\% molecular screening agarose gel run at $100 \mathrm{~V}$ for at least $2 \mathrm{~h}$. Gels are visualized with UV illumination and documented either by Polaroid photography or by a gel documentation system. The ribotypes are grouped according to their unique pattern and when possible, compared to expected ribotypes for known sequences (of the same length) from the same taxonomic group of interest. Otherwise, 5-10 representatives from each unique ribotype are sequenced for identification or confirmation of presumptive identification based upon expected ribotype pattern.

Further library analysis requires a computer with a set of programs for sequence analysis and Internet access. First sequences from each template are assembled and checked on-line for integrity using the CHIMERA_CHECK program at the Ribosomal Database Project II (http://rdp.cme.msu.edu/cgis/chimera.cgi?su=SSU). This is an important step for cleaning-up a library by eliminating PCR-generated artefacts, such as chimeric sequences. The sequences that passed quality control are aligned together with the type strains and similar sequences from databases. This alignment now can be used for phylogenetic reconstruction using various methods such as neighbourjoining, maximum parsimony or maximum likelihood followed by statistical analysis, such as bootstrapping.

Based on the number of species retrieved (OTUs) and population numbers within the species (number of clones forming an OTU), the ecosystem parameters, such as library coverage, general diversity indices, evenness and species richness, can be elucidated.

\section{Procedures, equipment and reagents}

For each animal, fresh rumen content samples should be used and transported on ice in a tightly closed tube to prevent further microbial activity. In a lab, rumen content can be fractionated if desired and immediately frozen and stored at $-80^{\circ} \mathrm{C}$. Methods to collect, fractionate and extract DNA from rumen digesta and PCR amplification protocols are suggested in Chapter 3.

There are several methods of total DNA isolation, including commercially available kits (e.g. Qiagen QIamp ${ }^{(\mathbb{R})}$ DNA Stool Mini Kit, Qiagen, Valencia, CA), bead-beating technique, freezing-thawing method or enzymatic lysis. In our experience of bacterial library construction, the bead-beating method, which is also implemented in some kits, results in the maximum recovery of diversity, while the enzymatic lysis method generates libraries biased toward over-representation of Gram-negative bacteria belonging to the CFB phylum (Tajima et al., unpublished observations). Despite the higher probability of chimera formation with template DNA produced by beadbeating, it remains the method of choice for production of PCR-generated SSU-rDNA libraries. This is, in part, because no high-molecular weight DNA is required for this application and the probability of cell disintegration is independent of the cell wall structure. 
There are some concerns about library generation by PCR, in that, the number of cycles must be kept as small as possible. It has been shown for the human gut community that the 25-cycle rDNA library displays reduced diversity than the 10cycle library [3]. The smaller number of cycles imposes strict requirements to DNA quality; it can be additionally purified by gel-filtration, cesium chloride $(\mathrm{CsCl})$ gradient centrifugation or agarose electrophoresis, if PCR-inhibiting substances are suspected in DNA preparations. Another point of the library quality issues is the annealing temperature during PCR. A significant increase in number of OTUs retrieved can be achieved by lowering the annealing temperature [12].

It is also important to mention that most commercial cloning kits use the Aoverhang artefact that is generated by Taq polymerase and PCR products are ligated into plasmids designed with a T-overhang. Therefore, on the last PCR cycle, the primer extension should be between 7 and $10 \mathrm{~min}$ long to ensure completion of the A-overhangs. This will also improve your cloning efficiency. Because there are many commercial cloning kits available, such as the TA cloning kit (Invitrogen), pGEM-T cloning kit (Promega), the Sure Clone Ligation Kit (Pharmacia), etc., it is important to follow the manufacturers instructions. PCR primers used to amplify bacterial, archaeal, protozoal and fungal SSU-rDNA are shown in Table 1.

\section{Cloning}

1. After PCR, the mix can be used directly in the cloning reaction with TOPO TA cloning kit (Invitrogen, CA, USA). This kit uses topoisomerase-mediated incorporation of PCR amplicons into the T-overhang vector pCR4 and all cloning procedures can be done within $2 \mathrm{~h}$.

2. To ensure colonies are well spread on the 1.2\% LBAXI agar plates (LB agar containing Ampicillin, Xgal and IPTG) (Sigma; Appendix VI), spread three different volumes $(120 \mu, 80 \mu$ and $50 \mu \mathrm{l})$ using a hockey stick and incubate at $37^{\circ} \mathrm{C}$ for $14-16 \mathrm{~h}$.

If using TOP10 cells, no IPTG is required for blue/white screening.

(Note: A bacterium without an insert in the plasmid forms blue colonies (i.e. negative) and a bacterium with an insert in the plasmid forms white colonies in the presence of Xgal (i.e. positive) [25].)

3. Remove the plates with the transformed colonies and store at $4{ }^{\circ} \mathrm{C}$ for several hours to increase the intensity of blue (i.e. negative) colonies.

\section{Clone confirmation}

1. Use the blunt end of an autoclaved toothpick to gently touch the centre of a single white colony and make three streaks $1-2 \mathrm{~cm}$ long onto a new 1.2\% LBAXI agar plate. Repeat this step using a new toothpick for each white colony, and then incubate at $37^{\circ} \mathrm{C}$ for $12-16 \mathrm{~h}$.

2. Remove LBAXI agar plates and check triple streaks for blue colouration. Disregard blue steaks and number only those sets of triple streaks that are white. 
Table 1. Primers used for library construction and analysis

\begin{tabular}{lll}
\hline Primer ID & Primer sequence & References \\
\hline Archaea & & \\
025eF & 5'-CTG GTT GAT CCT GCC AG & {$[1]$} \\
1492R & 5'-GGT TAC CTT GTT ACG ACT & {$[1]$} \\
D30 & 5'-ATT CCG GTT GAT CCT GC & {$[2]$} \\
D33 & 5'-TCG CGC CTG CGC CCC GT & {$[2]$} \\
Met83F & 5'-ACK GCT CAG TAA CAC & {$[44]$} \\
Met86F & 5'-GCT CAG TAA CAC GTG G & {$[44]$} \\
Met1340R & 5'-CGG TGT GTG CAA GGA G & {$[44]$} \\
Ar1000 & 5'-AGTCAGGCAACGAGCAGA & {$[38]$} \\
Ar1500 & 5'-GGTTACCTTGTTACGACTT & {$[38]$} \\
Bacteria & & \\
$27 f$ & & {$[16]$} \\
$519 f$ & 5' AGA GTT TGA TCM TGG CTC AG & {$[16]$} \\
519r & 5' CAG CMG CCG CGG TAA TWC & {$[16]$} \\
926r & 5' GWA TTT TAC CGC GGC KG C TG & {$[16]$} \\
926f & 5' CCG TCA ATT CMT TTR AGT TT & {$[16]$} \\
$1492 \mathrm{r}$ & 5' AAA CTY AAA KGA ATT GAC GG & {$[16]$} \\
1525r & 5' TAC GGY TAC CTT GTT ACG ACT T & {$[16]$} \\
Eukarya & 5' AAG GAG GTG WTC CAR CC & \\
Medlin B & & {$[19]$} \\
Fungi & 5'-TGA TCC TTC TGC AGG TTC ACC TAC & \\
nu-SSU-0817f & & {$[4]$} \\
nu-SSU-1196r & 5' TTA GCA TGG AAT AAT RRA ATA GGA & {$[4]$} \\
nu-SSU-1536r & 5' TCT GGA CCT GGT GAG TTT CC & {$[4]$} \\
Protozoa & 5' ATT GCA ATG CYC TAT CCC CA & {$[13]$} \\
P-SSU-342F & 5'-CTT TCG ATG GTA GTG TAT TGG ACT AC & \\
\hline
\end{tabular}

3. For each group of white streaks, use the blunt end of an autoclaved toothpick to collect cells from one of the three streaks. Pick one blue streak and use it as your negative control.

4. Stick toothpick and cells into $15 \mu \mathrm{l}$ of distilled $\mathrm{H}_{2} \mathrm{O}$ in a $0.6 \mathrm{ml}$ microfuge tube. Twist toothpick in the distilled $\mathrm{H}_{2} \mathrm{O}$ to dislodge the bacterial cells (water should turn cloudy) and discard the toothpick into a biohazardous waste autoclave bag. Do not leave toothpick in tube or it will absorb the solution.

5. Add $15 \mu \mathrm{l}$ of $2 \times$ plasmid cracking buffer and vortex. Bacterial cells are lysed when the solution turns clear.

6. Add $30 \mu \mathrm{l}$ of distilled $\mathrm{H}_{2} \mathrm{O}$ to the solution and then add $5 \mu \mathrm{l}$ of $6 \times$ dye.

To check for plasmids containing the correct size insert, load $30 \mu 1$ of each tube onto a $1.0 \%$ agarose gel and run for $1 \mathrm{~h}$ at $100 \mathrm{~V}$. First load a DNA molecular marker and then the sample from the negative control (i.e. blue streak containing plasmid only).

(Note: The DNA will be supercoiled, so it will migrate faster than linear DNA. To determine the approximate size of your positive clone on the gel, take the size of your plasmid and add the size of your PCR product and then look for a band at approximately $60 \%$ of your calculation. For example, if your plasmid is $2.9 \mathrm{~kb}$ 
and your insert is $1.3 \mathrm{~kb}$ insert (4.2 kb total), then $60 \%$ of $4.2 \mathrm{~kb}$ would be the supercoiled size.)

7. Identify and label all samples of the correct molecular weight (i.e. those larger than the negative control).

8. Aseptically remove one of the two remaining triple streaks from each positive clone using an inoculation loop or an autoclaved toothpick and inoculate test tubes containing $10 \mathrm{ml}$ of LB broth and Ampicillin.

9. Agitate tubes overnight on a platform shaker at $37^{\circ} \mathrm{C}$.

(Note: The remaining streak can be used as a backup or to make glycerol stocks for storage.)

\section{Alternative rapid protocol for clone confirmation}

If you have access to a genomics facility, recombinant colonies are picked up using an automated colony picker into the 96- or 384-well format microtitre plates. The cells are grown overnight in $2 \times$ LB or terrific broth and archived with $20 \%$ glycerol or $7 \%$ DMSO at $-80^{\circ} \mathrm{C}$. The liquid handling robot is then used for PCR amplification using $1 \mu \mathrm{l}$ of cell suspension as a template and vector primers (M13 or T3 + T7). One microlitre of the resulting PCR is used for sequencing PCR. If no high-throughput facility is available, follow the protocol given below.

1. Prepare PCR master mix with BIOTAQ Red polymerase (Bioline) and M13 or T3 and T7 primers.

2. Dispense $15 \mu \mathrm{l}$ aliquots into a 96-well PCR plate on ice using a 12-channel pipette.

3. Use a sterile plastic toothpick to gently touch the centre of a single white colony and dip it into the PCR mix for 1-2 s. Then inoculate the biomass remaining on a toothpick to a corresponding grid on a 96-well microtitre plate with $\times 2$ LB or terrific broth. Repeat the step using a new toothpick for each white colony.

4. Pick a blue colony as a negative control.

5. Seal the plate and run PCR with initial DNA denaturation at $95^{\circ} \mathrm{C}$ for $10 \mathrm{~min}$, followed by 35 cycles of $95^{\circ} \mathrm{C}$ for $10 \mathrm{~s}, 55^{\circ} \mathrm{C}$ for $10 \mathrm{~s}$ and $72^{\circ} \mathrm{C}$ for $30 \mathrm{~s}$, then the final elongation step at $72^{\circ} \mathrm{C}$ for $10 \mathrm{~min}$ and hold at $4^{\circ} \mathrm{C}$.

6. In the meantime, prepare a $1 \%$ agarose gel in TBE with a GelStar fluorescent dye (BMC).

7. Load $5 \mu \mathrm{l}$ aliquots into the gel directly from the PCR plate using a 12-channel pipette. No need to add loading buffer. Run phoresis at $100 \mathrm{~V}$ for $1 \mathrm{~h}$.

8. After electrophoresis, document the gel with the GelDoc system. 'Empty' clones will produce a small PCR product, 150-190 bp of length, migrating together with the negative control, while recombinants will produce larger amplicons (ca. $1.5 \mathrm{~kb}$ if bacterial libraries were produced with $27 \mathrm{f}$ and $1525 \mathrm{r}$ or $27 \mathrm{f}$ and $1492 \mathrm{r}$ primer pairs).

9. The remaining PCR product (step 7) can be stored at $4^{\circ} \mathrm{C}$ for sequencing with a single primer (e.g. with $27 \mathrm{f}$ primer in a bacterial library that was produced with $27 \mathrm{f}$ and $1492 \mathrm{r}$ primers) to define the number of OTUs in your library. 
10. Incubate the plate from step 3 at $37^{\circ} \mathrm{C}$ for $12-16 \mathrm{~h}$ with gentle agitation and archive it at $-80^{\circ} \mathrm{C}$ after adding glycerol (20\% final concentration) or DMSO $(7 \%)$.

\section{Plasmid miniprep}

Plasmids are harvested and purified from the overnight cultures using plasmid minipreps such as the Flexi-Prep $100 \mathrm{Kit}$ (Qiagen) and GenElute ${ }^{\mathrm{TM}}$ Plasmid Miniprep kit (Sigma). The plasmid insert is then re-amplified by PCR using the vector-specific primer, usually M13 or T3 and T7.

\section{Determination of OTUs by ribotyping}

1. Frequent-cutting restriction endonucleases are used, in accordance with manufacturer's specifications, to digest the amplified SSU-rDNA sequence.

2. Digested fragments with a $100 \mathrm{bp}$ DNA molecular weight marker (to determine the size of the bands) are then separated by gel electrophoresis performed at $100 \mathrm{~V}$ for $2 \mathrm{~h}$ on high-resolution 3-4\% molecular screening agarose gel.

3. Gels are visualized with UV illumination and ribotypes documented either by Polaroid photography or by a gel documentation system.

4. Ribotypes are grouped according to their unique pattern.

5. At least 5-10 representatives from each unique ribotype are sequenced for identification, ideally in both directions using a set of primers covering the whole amplicon.

\section{Determination of OTUs by sequencing}

1. Perform sequencing PCR with a $1 \mu$ template from a positive PCR reaction (Chapter 3) and an internal sequencing primer (e.g. 338F for bacterial libraries, or Met448F for methanogen libraries [44]).

(Note: If PCR was performed with a large excess of primers and dNTPs, they may interfere with the subsequent sequencing PCR and need to be removed by ExoSAP-IT (Amersham Biosciences). For this, add $1 \mu 1$ of the ExoSAP-IT enzyme mix to $5 \mu \mathrm{l}$ of PCR product and incubate at $37^{\circ} \mathrm{C}$ for $15 \mathrm{~min}$, followed by enzymes inactivation at $80^{\circ} \mathrm{C}$ for $15 \mathrm{~min}$. Use $1 \mu \mathrm{l}$ of it in cycle sequencing (e.g. with BigDye v.3.1, Applied Biosystems, or other chemistries.)

2. Clean up the sequences and generate a DNA similarity matrix. Reads with more than $97 \%$ similarity represent a single OTU and 1-2 clones from each OTU are submitted to complete sequencing by a combination of primers covering the whole amplicon on both strands (e.g. in the case of $27 \mathrm{r}$ and 1492r-generated bacterial libraries, these are 27f, 338f, 338r, 907r, 926f and 1492r; or in the case of Met83F or Met86F and Met1340R-generated methanogen libraries these are Met86F, Met448F, Met448R, Met1027F, Met1027R and Met1340R [44]). 


\section{Bioinformatics}

Phylogenetic classification is an evolutionary hypothesis of a historical sequence of speciation events that suggests that species or groups of species classified together are more closely related genealogically to each other than they are to any other taxa $[10,41]$. This system is based on the principle of homology and uses a priori arguments based on comparisons to an outgroup. Theoretically, any taxonomic unit not in the ingroup can be used as the outgroup. However, ideally you should use the sister group for comparisons [18, 27, 29, 36].

1. Assemble several sequencing reads of each OTU using Sequencher or AutoAssembler (PE-Applied Biosystem). Clean up from vector sequences and edit the sequence if necessary.

2. Check the integrity of your sequence using the CHIMERA_CHECK program at the Ribosomal Database Project II (http://rdp.cme.msu.edu/cgis/chimera.cgi?su = SSU).

3. Align new sequences against existing sequences for your taxonomic group using sequence alignment software such as Dedicated Comparative Sequence Editor (DCSE) [23] or CLUSTALX [33] (available at http://www-igbmc.ustrasbg.fr/BioInfo/ClustalX/Top.html). For phylogenetically coherent sequences, remember to use sequences from closely related species for your outgroup. If the library is generated with primers targeting the larger order taxa such as the Bacteria domain, use the deep-branching sequences of Thermotoga and Aquifex.

4. Check the alignment quality and edit if necessary (now the alignment is ready for phylogenetic analysis). A phylogenetic inference package such as PHYLIP (v. 3.51C) [6] can be used to calculate the sequence similarity and evolutionary distances between pairs of nucleotide sequences using a distance model such as the Kimura two-parameter model [14].

5. Construct a distance-matrix tree using either the Fitch and Margoliash least squares method [7] or the neighbour-joining method [24].

6. To determine the stability of particular groups of taxa, bootstrap resamples [5] the data 1000 times. When phylogenetic trees are constructed by distance-matrix methods, the horizontal length of the branches produced from the analysis indicates the amount of genetic difference between the organisms, in relation to each other on the tree.

7. Visualize and edit the tree using TreeView, NJ plot, or MacClade program.

\section{The Shannon index values}

The Shannon index illustrates the difference in diversity between SSU-rDNA clone libraries. The Shannon index $(H)$ of general diversity can be calculated for each clone library using the following equation [20].

$$
H=-\sum\left(\frac{n i}{N}\right) \times \log \left(\frac{n i}{N}\right)
$$


where $n i=$ importance value for each species

$N=$ total of importance values

The Shannon index is calculated as follows: the total importance value is the total number of clones identified in that sample. Thus, the importance value for the individual clone was the number of times it was identified in the sample. The SSU-rDNA clone library with the greatest diversity has the highest Shannon index value.

\section{Rarefaction analysis}

The diversity of your clone libraries can be estimated by rarefaction analysis [9] using the Analytic Rarefaction v.1.3 program (S.M. Holland, University of Georgia), which is freely available on the Web (www.uga.edu/strata/software).

\section{Library coverage}

The library coverage value is calculated according to Good [8] using the formula $[1-(n / N)]$, where $n$ is the number of OTUs represented only by a single clone and $N$ is the total number of clones in the library. The more unique OTUs in the library, the lower the diversity coverage. This approach also helps to test whether two libraries (e.g. from different diets) are significantly different and can be calculated with the LIBSHUFF program [26] available on the Web (www.arches.uga.edu/ whitman/libshuff.html).

\section{Solutions}

1.0 M Tris- $\mathrm{HCl}, \mathrm{pH} 8.0$

$0.5 \mathrm{MNa}$-EDTA, $\mathrm{pH} 8.0$

$0.5 \mathrm{MNa}$-EDTA, $\mathrm{pH} 7.5$

$5 \mathrm{M} \mathrm{NaCl}$

Xgal/IPTG $(5: 1)$ solution

- 5-Bromo-4-chloro-3-indolyl galactopyranoside (Xgal) $100 \mathrm{mg}$

- Isopropyl thio- $\beta$-D-galactoside (IPTG) $200 \mathrm{mg}$

- Dimethylformamide $5 \mathrm{ml}$

- Autoclaved distilled $\mathrm{H}_{2} \mathrm{O} \quad 1 \mathrm{ml}$

Dissolve $100 \mathrm{mg}$ of Xgal in $5 \mathrm{ml}$ of dimethylformamide $(20 \mathrm{mg} / \mathrm{ml})$.

Dissolve $200 \mathrm{mg}$ of IPTG in $1.0 \mathrm{ml}$ of autoclaved distilled $\mathrm{H}_{2} \mathrm{O}(200 \mathrm{mg} / \mathrm{ml})$

Mix $5 \mathrm{ml}$ of Xgal solution with $1 \mathrm{ml}$ of IPTG and store at $-20^{\circ} \mathrm{C}$.

Luria Bertini (LB) broth

- $\mathrm{NaCl}$

$5.0 \mathrm{~g}$

- Yeast extract

$2.5 \mathrm{~g}$

- Bacto tryptone 
Mix ingredients and bring to $500 \mathrm{ml}$ with distilled $\mathrm{H}_{2} \mathrm{O}$, then aliquot $10 \mathrm{ml}$ into 40 test tubes. Use $100 \mathrm{ml}$ for $100 \times$ Ampicillin solution (see below). Autoclave test tubes, and when cool using sterile techniques add $100 \mu \mathrm{l}$ of the $100 \times$ Ampicillin solution to each tube. Store tubes at $4^{\circ} \mathrm{C}$.

\section{$100 \times$ Ampicillin solution}

- LB broth

$100 \mathrm{ml}$

- Ampicillin

$1.0 \mathrm{~g}$

Dissolve $1.0 \mathrm{~g}$ of Ampicillin into $100 \mathrm{ml}$ of LB broth. No need to autoclave as this is $100 \times$ recommended strength. Keep frozen at $-20^{\circ} \mathrm{C}$.

1.2\% LB-Ampicillin-Xgal-IPTG (LBAXI) agar

- $\mathrm{NaCl}$

$10.0 \mathrm{~g}$

- Yeast extract

$5.0 \mathrm{~g}$

- Bacto tryptone

$10.0 \mathrm{~g}$

- Agar

$12.0 \mathrm{~g}$

- Xgal : IPTG $(5: 1)$ solution

$1.0 \mathrm{ml}$

- $100 \times$ Ampicillin solution

$10.0 \mathrm{ml}$ (or $100 \mathrm{mg}$ Ampicillin)

Mix all dry ingredients and bring to 11 with distilled $\mathrm{H}_{2} \mathrm{O}$ and autoclave. When solution is cool enough to touch against wrist, add Ampicillin and $1 \mathrm{ml}$ of Xgal : IPTG $(5: 1)$ solution. Swirl the contents and pour into (30-40) Petri dishes.

\section{$2 \times$ Plasmid Cracking Buffer}

- $10 \mathrm{M} \mathrm{NaOH}$

$0.5 \mathrm{ml}$

- $0.5 \mathrm{M}$ Na-EDTA pH 8.0

$1.0 \mathrm{ml}$

- $20 \%(\mathrm{v} / \mathrm{v}) \mathrm{SDS}$

$2.5 \mathrm{ml}$

- Glycerol

$5.0 \mathrm{ml}$

- Distilled $\mathrm{H}_{2} \mathrm{O}$

$41.0 \mathrm{ml}$

Mix solution and store at room temperature. No need to autoclave.

$6 \times$ Dye

- Bromophenol blue (final concentration $0.3 \%$ )

$0.3 \mathrm{~g}$

- Xylene Cyanol FF (final concentration 0.3\%)

$0.3 \mathrm{~g}$

- $0.5 \mathrm{M}$ Na-EDTA (pH 7.5) (final concentration $10.0 \mathrm{mM}$ )

$2.0 \mathrm{ml}$

- $40 \%(\mathrm{w} / \mathrm{v})$ Glucose solution

$98.0 \mathrm{ml}$

Mix solution and store at $-20^{\circ} \mathrm{C}$. No need to autoclave.

\section{Other reagents and equipment}

DNA isolation kits, PCR kits, primers, pipettes and tips, electrophoresis unit, thermocycler, UV transilluminator, spectrophotometer (A260 $\mathrm{nm}$ capable), restriction enzymes, DNA size markers, agarose (multipurpose and molecular screening), centrifuge, incubator, water bath, capillary sequencer, computer and software for sequence alignment and phylogenetic analysis. 


\section{References}

1. Achenbach, L., and C. Woese. 1995. 16S and 23S rRNA-like primers, pp. 521-523. In K.R. Sower and H.J. Schreier (eds.), Archaea: A Laboratory Manual. Cold Spring Harbor Laboratory Press, Cold Spring Harbor, New York.

2. Arahal, D.R., F.E. Dewhirst, B.J. Paster, B.E. Volcani, and A. Ventosa. 1996. Phylogenetic analyses of some extremely halophilic archaea isolated from Dead Sea water, determined on the basis of their $16 \mathrm{~S}$ rRNA sequences. Appl. Environ. Microbiol. 62:3779-3786.

3. Bonnet, R., A. Suau, J. Dore, G.R. Gibson, and M.D. Collins. 2002. Differences in rDNA libraries of faecal bacteria derived from 10- and 25-cycle PCRs. Int. J. Syst. Evol. Microbiol. 52:757-763.

4. Borneman, J., and R.J. Hartin. 2000. PCR primers that amplify fungal rRNA genes from environmental samples. Appl. Environ. Microbiol. 66:4356-4360.

5. Felsenstein, J. 1985. Confidence limits on phylogenies: an approach using the bootstrap. Evolution 39:783-791.

6. Felsenstein, J. 1993. PHYLIP (Phylogeny Inference Package) documentation files. Version $3.51 \mathrm{c}$. Distributed by the author, Department of Genetics, University of Washington, Seattle, WA.

7. Fitch, W.K., and E. Margoliash. 1967. Construction of phylogenetic trees. Science 155:279-284.

8. Good, I.J. 1953. The population frequencies of species and the estimation of population parameters. Biometrika 40:237-262.

9. Heck, K.L., G. Van Belle Jr., and D. Simberloff. 1975. Explicit calculation of the rarefaction diversity measurement and determination of sufficient sample size. Ecology 56:1459-1461.

10. Hennig, W. 1966. Phylogenetic Systematics, 264 pp. University of Illinois Press, Urbana, IL.

11. Hespell, R.B., D.E. Akin, and B.A. Dehority. 1997. Bacteria, fungi, and protozoa of the rumen, pp. 59-141. In R.I. Mackie, B.A. White, and R.E. Isaacson (eds.), Gastrointestinal Microbiology, Vol. 2. Chapman \& Hall, New York.

12. Hongoh, Y., H. Yuzawa, M. Ohkuma, and T. Kudo. 2003. Evaluation of primers and PCR conditions for the analysis of 16S rRNA genes from a natural environment. FEMS Microbiol. Lett. 221:299-304.

13. Karnati, S.K., Z. Yu, J.T. Sylvester, B.A. Dehority, M. Morrison, and J.L. Firkins. 2003. Specific PCR amplification of protozoal $18 \mathrm{~S}$ rDNA sequences from DNA extracted from ruminal samples of cows. J. Anim. Sci. 81:812-815.

14. Kimura, M. 1980. A simple method of estimating evolutionary rates of base substitutions through comparative studies of nucleotide sequences. J. Mol. Evol. 16:111-120.

15. Kocherginskaya, S.A., R.I. Aminov, and B.A. White. 2001. Analysis of the rumen bacterial diversity under two different diet conditions using denaturing gradient gel electrophoresis, random sequencing, and statistical ecology approaches. Anaerobe 7:119-134.

16. Lane, D.J. 1991. 16S/23S rRNA sequencing, pp. 115-175. In E. Stackebrandt and M. Goodfellow (eds.), Nucleic Acid Techniques in Bacterial Systematics. Wiley and Sons, New York.

17. Lin, C., L. Raskin, and D.A. Stahl. 1997. Microbial community structure in gastrointestinal tracts of domestic animals: comparative analysis using rRNA-targeted oligonucleotide probes. FEMS Microbiol. Ecol. 22:281-294.

18. Maddison, W.P., M.J. Donoghue, and D.R. Maddison. 1984. Outgroup analysis and parsimony. Syst. Zool. 33:83-103.

19. Medlin, L., H.J. Elwood, S. Stickel, and M.L. Sogin. 1988. The characterization of enzymatically amplified eukaryotic 16S-like rRNA-coding regions. Gene 71:491-499.

20. Odum, P.E. 1971. Principles and concepts pertaining to organization at the community level, pp. 140-161. In Fundamentals of Ecology. W.B. Saunders Company, Philadelphia.

21. Ramsak, A., M. Peterka, K. Tajima, J.C. Martin, J. Wood, M.E. Johnston, R.I. Aminov, H.J. Flint, and G. Avgustin. 2000. Unravelling the genetic diversity of ruminal bacteria belonging to the CFB phylum. FEMS Microbiol. Ecol. 33:69-79.

22. Rieu-Lesme, F., J.J. Godon, and G. Fonty. 2000. Remarkable archaeal diversity detected in the rumen of a cow. Reprod. Nutr. Dev. 40:179-180.

23. Rijk, P. de, and R. de Wachter. 1993. DCSE, an interactive tool for sequence alignment and secondary structure research. Comput. Appl. Biosci. 9:735-740. 
24. Saitou, N., and M. Nei. 1987. The neighbor-joining method: a new method for reconstructing phylogenetic trees. Mol. Biol. Evol. 4:406-425.

25. Sambrook, J., E.F. Fritsch, and T. Maniatis. 1989. Molecular Cloning: A Laboratory Manual, 2nd ed., Vols. 1-3. Cold Spring Harbor Laboratory, Cold Spring Harbor, New York.

26. Singleton, D.R., M.A. Furlong, S.L. Rathbun, and W.B. Whitman. 2001. Quantitative comparisons of 16S rRNA gene sequence libraries from environmental samples. Appl. Environ. Microbiol. 67:43744376.

27. Smith, A.B. 1994. Rooting molecular trees: problems and strategies. Biol. J. Linn. Soc. 51:279-292.

28. Stackebrandt, E., and B.M. Goebel. 1994. A place for DNA-DNA reassociation and 16S ribosomalRNA sequence-analysis in the present species definition in bacteriology. Int. J. Syst. Bacteriol. 44:846849.

29. Stackebrandt, E., and W. Ludwig. 1994. The importance of using outgroup reference organisms in phylogenetic studies: the Atopobium case. Syst. Appl. Microbiol. 17:39-43.

30. Tajima, K., R.I. Aminov, T. Nagamine, K. Ogata, M. Nakamura, H. Matsui, and Y. Benno. 1999. Rumen bacterial diversity as determined by sequence analysis of $16 \mathrm{~S}$ rDNA libraries. FEMS Microbiol. Ecol. 29:159-169.

31. Tajima, K., S. Arai, K. Ogata, T. Nagamine, H. Matsui, M. Nakamura, R.I. Aminov, and Y. Benno. 2000. Rumen bacterial community transition during adaptation to high-grain diet. Anaerobe 6:273-284.

32. Tajima, K., T. Nagamine, H. Matsui, M. Nakamura, I. Rustam, and R.I. Aminov. 2001. Phylogenetic analysis of archaeal 16S rRNA libraries from the rumen suggests the existence of a novel group of archaea not associated with known methanogens. FEMS Microbiol. Lett. 200:67-72.

33. Thompson, J.D., T.J. Gibson, F. Plewniak, F. Jeanmougin, and D.G. Higgins. 1997. The ClustalX windows interface: flexible strategies for multiple sequence alignment aided by quality analysis tools. Nucleic Acids Res. 24:4876-4882.

34. Tokura, M., I. Chagan, K. Ushida, and Y. Kojima. 1999. Phylogenetic study of methanogens associated with rumen ciliates. Curr. Microbiol. 39:123-128.

35. Ward, D.M., M.M. Bateson, Z.R. Weller, and A.L. Ruff-Roberts. 1992. Ribosomal rRNA analysis of microorganisms as they occur in nature. Adv. Microbiol. Ecol. 12:219-286.

36. Watrous, L.E., and Q.D. Wheeler. 1981. The out-group comparison method of character analysis. Syst. Zool. 30:1-11.

37. Wayne, L.G., D.J. Brenner, R.R. Colwell, P.A.D. Grimont, O. Kandler, M.I. Krichevsky, L.H. Moore, W.E.C. Moore, R.G.E. Murray, E. Stackebrandt, M.P. Starr, and H.G. Truper. 1987. International committee on systematic bacteriology. Report of the adhoc committee on reconciliation of approaches to bacterial systematics. Int. J. Syst. Bacteriol. 37:463-464.

38. Weisburg, W.G., S.M. Barns, D.A. Pelletier, and D.J. Lane. 1991. 16S ribosomal DNA amplification for phylogenetic study. J. Bacteriol. 173:697-703.

39. Whitford, M.F., R.J. Forster, C.E. Beard, J. Gong, and R.M. Teather. 1998. Phylogenetic analysis of rumen bacteria by comparative sequence analysis of cloned 16S rRNA genes. Anaerobe 4:153-163.

40. Whitford, M.F., R.M. Teather, and R.J. Forster. 2001. Phylogenetic analysis of methanogens from the bovine rumen. BMC Microbiol. 1:5.

41. Wiley, E.O. 1981. Phylogenetics; The Principles and Practice of Phylogenetic Systematics, 439 pp. John Wiley and Sons, New York.

42. Wintzingerode, F. von, U.B. Gobel, and E. Stackebrandt. 1997. Determination of microbial diversity in environmental samples: pitfalls of PCR-based rRNA analysis. FEMS Microbiol. Rev. 21:213-229.

43. Wolin, M.J, T.L. Miller, and C.S. Stewart. 1997. Microbe-microbe interactions. In P.N. Hobson and C.S. Stewart (eds.), The Rumen Microbial Ecosystem. Blackie Academic and Professional, New York.

44. Wright, A.-D.G., and C. Pimm. 2003. Improved strategy for presumptive identification of methanogens using 16S riboprinting. J. Microbiol. Methods 55:337-349.

45. Yanagita, K., Y. Kamagata, M. Kawaharasaki, T. Suzuki, Y. Nakamura, and H. Minato. Phylogenetic analysis of methanogens in sheep rumen ecosystem and detection Methanomicrobium mobile by fluorescence in situ hybridization. Biosci. Biotechnol. Biochem. 64:1737-1742. 